\title{
PERBANDINGAN EXPONENTIAL SMOOTHING HOLT-WINTERS DAN ARIMA PADA PERAMALAN PRODUKSI PADI DI PROVINSI GORONTALO
}

\author{
Ingka Rizkyani Akolo') \\ ${ }^{1}$ Program Studi Teknologi Hasil Pertanian, Politeknik Gorontalo \\ Email: inkarizkyani05@gmail.com ${ }^{1)}$
}

\begin{abstract}
ABSTRAK
Gorontalo merupakan salah satu provinsi di Indonesia yang memiliki lahan pertanian yang besar yang sebagian besar ditanami padi. Kebutuhan bahan pangan padi di Gorontalo bertambah dari tahun ke tahun sesuai dengan pertambahan penduduk. Akan tetapi, karena terjadi perbedaan hasil panen padi di setiap daerah mengakibatkan kelangkaan beras sehingga mempengaruhi pemenuhan kebutuhan dan stabilitas penyediaan pangan di Gorontalo. Untuk membuat perencanaan terkait komoditas akan pangan diperlukan model matematika khusus untuk peramalan. Salah satunya model yang sering digunakan untuk peramalan adalah dalam peramalan adalah metode metode exponential smoothing Holt-Winters dan Autoregressive Integrated Moving Average (ARIMA). Tujuan dari penelitian ini adalah untuk mengetahui model peramalan produksi padi di Provinsi Gorontalo menggunakan metode exponential smoothing Holt-Winters dan ARIMA sehingga dapat memberikan masukan kepada Pemerintah Daerah dalam mengambil kebijakan yang berkaitan dengan ketahanan pangan di Provinsi Gorontalo. Hasil analisis menunjukkan bahwa model peramalan terbaik adalah Model peramalan produksi padi dengan metode ARIMA $(3,1,3)$ yang memberikan nilai RMSE lebih kecil dibandingkan metode exponential smoothing Holt-Winters.
\end{abstract}

Kata kunci: arima, exponential smoothing Holt-Winters, gorontalo, peramalan, produksi padi

\section{ABSTRACT}

Gorontalo is one of the provinces in Indonesia that has large agricultural land which is mostly planted with rice. The food demand for rice in Gorontalo increases from year to year according to population growth. However, due to differences in rice yields in each region resulting in scarcity of rice, it affected the fulfillment of the needs and stability of food supply in Gorontalo. To plan for commodities related to food, a special mathematical model for forecasting is needed. One model that is often used for forecasting are Holt-Winters exponential smoothing method and the Autoregressive Integrated Moving Average (ARIMA) method. The purpose of this study was to determine the forecasting model of rice production in Gorontalo Province using the HoltWinters and ARIMA exponential smoothing method so that it could provide input to the Regional Government in taking policies related to food security in Gorontalo Province. The results of the analysis show that the best forecasting model is ARIMA $(3,1,3)$ which gives a smaller RMSE value than the exponential smoothing HoltWinters method.

Keywords: arima, exponential smoothing Holt-Winters, gorontalo, prediction, rice production.

\section{PENDAHULUAN}

Indonesia merupakan salah satu negara berkembang yang mayoritas penduduknya menggantungkan hidupnya pada sektor pertanian dan menjadikannya sebagai sumber mata pencaharian. Gorontalo merupakan salah satu provinsi di Indonesia yang memiliki lahan pertanian yang besar. Tanaman pangan yang banyak diusahakan oleh rumah tangga petani di Gorontalo adalah padi. Padi merupakan komoditas pangan yang diolah menjadi bahan makanan pokok yaitu beras. Kebutuhan bahan pangan padi di Indonesia khususnya Gorontalo bertambah dari tahun ke tahun sesuai dengan pertambahan penduduk (Aisha, 2016).

Berdasarkan data Badan Pusat Statistika (BPS) provinsi Gorontalo, produksi padi di Provinsi Gorontalo tahun 2014 mencapai 303.627 ton meningkat dibandingkan dengan produksi padi tahun 
2013 yang produksinya sebanyak 290.231 ton. Peningkatan produksi padi tahun 2014 disebabkan karena meningkatnya luas panen tanaman padi (Badan Pusat Statistik, 2018). Hal ini berarti bahwa sebenarnya negara Indonesia mampu untuk memenuhi kebutuhan pangan terutama beras secara mandiri. Ironisnya, Indonesia yang menduduki peringkat ketiga tertinggi dalam penghasil beras terbesar di dunia ternyata juga memenuhi kebutuhan dan menjaga stabilitas penyediaan pangan nasional dengan mengimpor dari negara lain. Selain itu, perbedaan hasil panen di setiap daerah mengakibatkan kelangkaan beras karena tidak optimalnya teknik pertanian yang digunakan (Ramadhona dkk, 2018).

Menurut Wei (2006), data pertanian termasuk dalam kategori data timeseries. Dengan demikian untuk membuat perencanaan terkait komoditas akan pangan diperlukan model matematika salah satunya model yang sangat populer yaitu Time Series atau runtun waktu. Time series adalah suatu deret data yang dikumpulkan berdasarkan urutan waktu dengan interval yang sama. Data time series banyak dicatat dalam berbagai bidang seperti pertanian, pariwisata, ekonomi dan bisnis, kesehatan dan lain lain. Metode time series yang sering digunakan dalam peramalan adalah metode metode exponential smoothing HoltWinters dan Autoregressive Integrated Moving Average (ARIMA).

Data pertanian seperti data hasil produksi biasanya mempunyai pola musiman (Aisha, 2016). Pola musiman mampu dianalisis dengan metode exponential smoothing Holt-Winters dan Autoregressive Integrated Moving Average (ARIMA). Kelebihan dari metode exponential smoothing Holt-Winters adalah metode ini sangat baik meramalkan pola data yang berpengaruh musiman dengan unsur trend yang timbul secara bersamaan, metode yang sederhana dan mudah dimasukkan ke dalam praktek dan kompetitif terhadap model peramalan yang lebih rumit (Safitri, 2016). Sedangkan kelebihan ARIMA adalah memiliki sifat fleksibel (mengikuti pola data), tingkat akurasi peramalan cukup tinggi dan cocok digunakan untuk memprediksi dengan cepat, sederhana, akurat dan murah (Hutasuhut 2014).

Tujuan dari penelitian ini adalah untuk mengetahui model peramalan produksi padi di Provinsi Gorontalo menggunakan metode exponential smoothing Holt-Winters dan ARIMA sehingga dapat memberikan masukan kepada
Pemerintah Daerah dalam mengambil kebijakan yang berkaitan dengan ketahanan pangan di Provinsi Gorontalo.

\section{TINJAUAN PUSTAKA}

\subsection{Produksi Padi}

Menurut Assauri (2006) dalam Nurrohmah (2016) Produksi merupakan segala kegiatan dalam menciptakan dan menambah kegunaan (utility) suatu barang dan jasa. Produksi pada dasarnya merupakan kegiatan yang dimaksudkan untuk menghasilkan barang/jasa untuk dapat memenuhi kebutuhan manusia. Sedangkan definisi padi Menurut Sugeng (1992) dalam Krismiasari (2012) merupakan tanaman yang membutuhkan air cukup banyak dan berasalah dari golongan rumput-rumputan. Berdasarkan definisi para ahli diatas, diketahui bahwa produksi padi adalah kegiatan yang dimaksudkan untuk menghasilkan padi guna memenuhi kebutuhan manusia.

\subsection{Peramalan}

Menurut Subagyo (1986) dalam Krismiasari (2012) Peramalan adalah perkiraan atau prediksi mengenai sesuatu yang belum terjadi pada waktu yang akan datang. Pendapatan perkapita, jumlah penduduk, produksi, dan sebagainya selalu berubahubah. Perubahan ini dipengaruhi oleh faktor-faktor yang sangat kompleks. Misalnya penghasilan keluarga, tenaga kerja, kebudayaan masyarakat, lahan dan sebagainya. Perubahan tersebut sulit untuk ditentukan sebelumnya secara pasti. Oleh karena itu perlu adanya prediksi, dengan kata lain prediksi bertujuan untuk mendapatkan ramalan pada waktu yang akan datang dengan sedikitnya kesalahan dalam meramal.

\subsection{Time Series}

Time series merupakan serangkaian pengamatan yang terjadi secara berurutan pada interval waktu yang tetap (Wei, 2006). Menurut Makridakis, et al (1999) dalam Safitri (2016) langkah penting dalam memilih suatu metode runtun waktu (time series) yang tepat adalah dengan mempertimbangkan jenis pola data, sehingga metode yang paling tepat dengan pola data tersebut dapat diuji. Pola data dapat dibedakan menjadi empat, yaitu. (1) Pola horizontal terjadi pada saat ini data berfluktuasi di sekitar nilai ratarata konstan (deret seperti itu adalah stasioner terhadap nilai rataratanya); (2) Pola musiman terjadi jika suatu deret 
dipengaruhi oleh faktor musiman. Pola musiman merupakan fluktuasi dari data yang terjadi secara periodik dalam kurun waktu satu tahun, seperti triwulan, kuartalan, bulanan, mingguan, atau harian. Pola ini sulit dideteksi dan tidak dapat dipisahkan dari pola trend. Seperti pada penjualan minuman ringan, es krim, bahan bakar pemanas ruangan; (3) Pola siklis terjadi bilamana datanya dipengaruhi oleh fluktuasi ekonomi jangka panjang seperti yang berhubungan dengan silkus bisnis; (4) Pola trend terjadi jika data terdapat pertambahan atau kenaikan atau penurunan sekuler jangka panjang dalam data.

\subsubsection{Metode exponential smoothing Holt- Winters}

Exponential smoothing Holt-Winters tepat digunakan jika data hanya dipengaruhi pola trend. Namun, jika data tidak hanya dipengaruhi pola trend, tetapi juga pola musiman, maka Eksponensial Holt smoothing tidak tepat digunakan untuk melakukan peramalan karena tidak dapat mendeteksi adanya pola musiman. Oleh karena itu, Winters menyempurnakan eksponensial Holt smoothing dengan menambahkan satu parameter untuk mengatasi pola musiman pada data. Metode yang memuat parameter trend dan musiman ini dinamakan metode exponential smoothing Holt-Winters. Metode ini dibagi menjadi dua model, yaitu model aditif dan multiplikatif. Perhitungan dengan model aditif dilakukan jika plot data asli menunjukkan fluktuasi musim yang relatif stabil, sedangkan model multiplikatif digunakan jika plot data asli menunjukkan fluktuasi musim yang bervariasi (Safitri, 2016)

Menurut Makridakis, et.al (1999) dalam Safitri (2016), ada tiga persamaan yang digunakan dalam metode ini, yaitu:

- Pemulusan eksponensial data asli

$$
S_{t}=\alpha \frac{X_{t}}{I_{t-L}}+(1+\alpha)+\left(S_{t-1}+b_{t-1}\right)
$$

- $\quad$ Pemulusan pola trend

$$
b_{t}=\gamma\left(S_{t}-S_{t-1}\right)+(1-\gamma) b_{t-1}
$$

- pemulusan pola musiman

$$
I_{t}=\delta \frac{X_{t}}{S_{t}}+(1-\delta) I_{t-L}
$$

- Ramalan $m$ periode ke depan:

$$
\hat{Y}_{t-m}=\left(S_{t}+b_{t} m\right) I_{t-L+m}
$$

dengan $I_{t}=$ nilai pemulusan musiman waktu ke- $t, S_{t}$ $=$ nilai pemulusan eksponensial waktu ke- $t, \quad X_{t}=$ data ke- $t, \alpha=$ konstanta pemulusan data asli $(0<\alpha<1), \delta=$ konstanta pemulusan pola musiman $(0<\delta<1), \gamma=$ konstanta pemulusan pola trend $(0<\gamma<1), \quad L=$ panjang musiman, $\quad b_{t}=$ konstanta pemulusan musiman pada waktu $t, m=$ jumlah periode yang akan diramalkan, $\quad \hat{Y}_{t-m}=$ nilai peramalan untuk $m$ periode ke depan.

\subsubsection{ARIMA}

Metode time series yang paling popular dan banyak digunakan dalam peramalan adalah Autoregressive Integrated Moving Average atau yang dikenal dengan model ARIMA. asumsi yang harus dipenuhi dalam pemodelan ARIMA adalah stasioneritas data dan error atau residual bersifat white noise. White noise berarti residual tidak berautokorelasi dan berdistribusi normal. Uji yang digunakan untuk menguji kondisi stasioneritas data adalah uji Augmented Dickey Fuller sedangkan uji yang digunakan untuk mendeteksi kondisi white noise dan normalitas masing-masing adalah uji Ljung-Box dan uji Kolmogorov-Smirnov (Nugraha dkk, 2018).

Bentuk umum ARIMA (p,d,q) dengan d merupakan orde dari differencing adalah sebagai berikut.

$$
\begin{gathered}
\phi_{p}(B)(1-B)^{d} Y_{t}=\theta_{q}(B) e_{t} \\
\text { dengan } \phi_{p}(B)=\left(1-\phi_{1} B-\phi_{2} B^{2}-\cdots-\phi_{p} B^{p}\right) \\
\theta_{q}(B)=\left(1-\theta_{1} B-\theta_{2} B^{2}-\cdots-\theta_{q} B^{q}\right)
\end{gathered}
$$

\section{METODOLOGI PENELITIAN}

Data yang digunakan dalam penelitian ini adalah data produksi padi di Provinsi Gorontalo tahun 2009 - 2018. Metode peramalan yang digunakan dalam penelitian ini ada dua, yakni metode Eksponensial Winter Smoothing dan metode ARIMA.

Tahapan penelitian yang digunakan dalam penelitian ini adalah sebagai berikut.

a. Melakukan plot data produksi padi terhadap waktu

b. Melakukan pemodelan data menggunakan metode exponential smoothing Holt-Winters

c. Melakukan pemodelan data menggunakan metode ARIMA dengan tahapan berikut.

- Melakukan uji stasioner data

- Jika data belum stasioner dalam rata-rata maka dilakukan differencing dan uji stasioner kembali 
- Menentukan model tentative ARIMA (p,d,q) dari pola ACF dan PACF

- Uji parameter model ARIMA menggunakan uji-t.

- Uji independensi, uji normalitas, dan white noise pada residual model ARIMA

- Jika diperoleh model ARIMA lebih dari satu, maka dilakukan pemilihan model ARIMA terbaik menggunakan kriteria, RMSE

- Melakukan peramalan menggunakan model ARIMA terpilih.

d. Membandingkan metode Eksponensial Winter Smoothing dan ARIMA serta memilih model terbaik menggunakan kriteria RMSE.

\section{HASIL DAN PEMBAHASAN}

\subsection{Karakteristik Produksi Padi di Gorontalo}

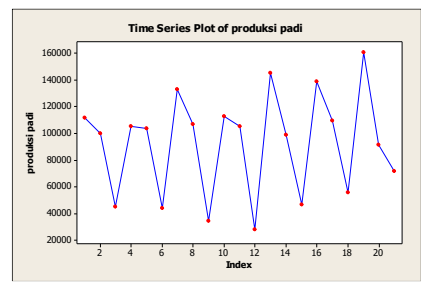

Gambar 1. Produksi padi provinsi Gorontalo per-caturwulan tahun 2009-2015

Gambar 1 menunjukkan bahwa produksi padi di Provinsi Gorontalo ada pola trend dan musiman. pola musimannya adalah 3 periode. Produksi padi juga terlihat meningkat dibandingkan tahun-tahun sebelumnya, khususnya pada periode 7, 13, 16 dan 19 atau produksi padi mengalami peningkatan pada periode Januari-April tahun 2011, Januari-April tahun 2013, Januari-April tahun 2014, dan JanuariApril tahun 2015. Setelah periode tersebut, produksi padi mengalami penurunan produksi. Hal ini memberikan gambaran bahwa produksi padi di Provinsi Gorontalo cukup fluktuatif.

\subsection{Peramalan Produksi Padi menggunakan Metode exponential smoothing Holt- Winters}

Metode exponential smoothing Holt-Winters ini menggunakan 3 parameter, yakni parameter level, parameter trend dan parameter musiman. Oleh karena itu, akan diperoleh beberapa model peramalan dengan parameter yang berbeda. Penentuan model terbaik pada peramalan produksi padi dengan metode ini dapat menggunakan nilai MAPE. Model yang diambil adalah model yang memiliki nilai MAPE terkecil. Berikut ini beberapa model peramalan produksi padi menggunakan metode exponential smoothing Holt-Winters multiplikatif.

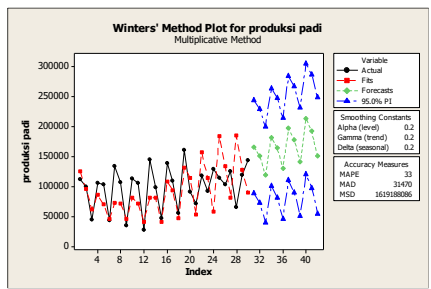

(a)

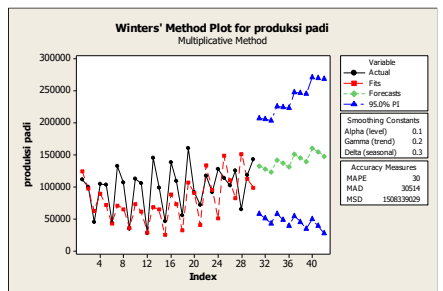

(b)

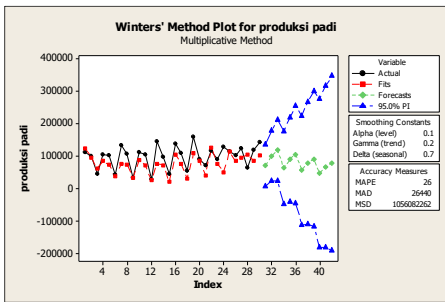

(c)

Gambar 2. (a) Plot model peramalan produksi padi dengan metode winters $(\alpha=0.2, \gamma=0.2, \delta=0,2)$; (b) Plot model peramalan produksi padi dengan metode winters $(\alpha=0.1, \gamma=0.2, \delta=0,3)$; (c) Plot model peramalan produksi padi dengan metode winters $(\alpha=0.1, \gamma=0.2, \delta=0,7)$.

Gambar 2 menunjukkan bahwa setelah proses trial-error dilakukan, diperoleh 3 model terbaik untuk peramalan produksi padi di Provinsi Gorontalo menggunakan metode eksponensial Winters smoothing. Berdasarkan Gambar 2 diketahui bahwa model terbaik yang memberikan nilai MAPE terkecil adalah model peramalan yang ditunjukkan oleh Gambar 2c. Model peramalan produksi padi dengan metode eksponensial Winters smoothing $(\alpha=0.1$, $\gamma=0.2, \delta=0,7)$ memberikan nilai MAPE sebesar 26 . Dengan demikian, model peramalan produksi padi di Provinsi Gorontalo dengan metode eksponensial Winters smoothing multiplikatif $(\alpha=0.1, \gamma=0.2$, $\delta=0,7)$ adalah sebagai berikut. 
- Pemulusan eksponensial data asli

$$
S_{t}=0.1 \frac{X_{t}}{I_{t-L}}+(1+0.1)+\left(S_{t-1}+b_{t-1}\right)
$$

- $\quad$ Pemulusan pola trend

$$
b_{t}=0.2\left(S_{t}-S_{t-1}\right)+(1-0.2) b_{t-1}
$$

- pemulusan pola musiman

$$
I_{t}=0.7 \frac{X_{t}}{S_{t}}+(1-0.7) I_{t-L}
$$

\subsection{Peramalan Produksi Padi menggunakan Metode ARIMA}

Peramalan produksi padi dengan metode ARIMA melalui beberapa tahapan. Tahapannya diuraikan sebagai berikut.

1. Tahapan pertama adalah memeriksa kestasioneran data melalui plot data produksi padi dan uji stasioner menggunakan uji Augmented Dickey Fuller.

Hipotesis:

$\mathrm{H}_{0}$ : data produksi padi merupakan unit root (tidak stasioner)

$\mathrm{H}_{0}$ : data produksi padi tidak unit root (data stasioner)

Berikut adalah hasil uji stasioner menggunakan uji unit root dengan bantuan software SAS yang disajikan dalam Tabel 1.

Tabel 1. Nilai Statistik Uji Augmented Dickey-Fuller Data Produksi Padi

\begin{tabular}{ccc}
\hline Data & $\tau_{\text {hitung }}$ & p_value \\
\hline Produksi Padi & -1.40 & 0.146 \\
\hline
\end{tabular}

Tabel 1 menunjukkan bahwa nilai p-value $=0.146>$ $\alpha=0.05$ sehingga gagal tolak $\mathrm{H}_{0}$. hal ini mengindikasikan bahwa data produksi padi belum stasioner.

2. Oleh karena data belum stasioner, maka alternative solusi yang dapat dilakukan adalah differencing untuk menstasionerkan data terhadap rata-rata. Differencing dilakukan 1 kali setelah itu dilakukan uji stasioner kembali.

Tabel 2. Nilai Statistik Uji Augmented Dickey-Fuller Data Produksi Padi setelah differencing 1 kali

\begin{tabular}{ccc}
\hline Data & $\tau_{\text {hitung }}$ & p_value \\
\hline Produksi Padi* $^{*}$ & $-9,37$ & $<0.0001$ \\
\hline
\end{tabular}

Tabel 2 menunjukkan bahwa nilai p-value ternyata $<0.0001$. Sehingga $\mathrm{p}$-value $<\alpha=0.05$ sehingga tolak $\mathrm{H}_{0}$. Hal ini mengindikasikan bahwa data produksi padi setelah dilakukan differencing 1 kali, ternyata sudah stasioner.

3. Menentukan model tentative ARIMA (p,d,q) dari pola ACF dan PACF

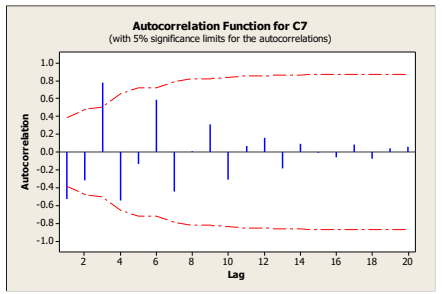

(a)

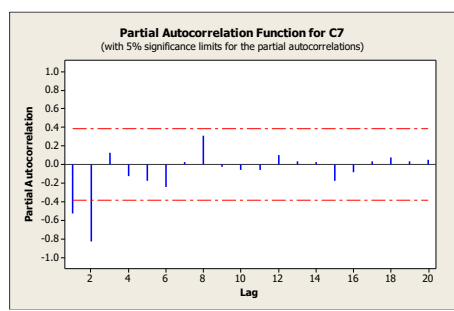

(b)

Gambar 3. (a) Plot ACF setelah differencing 1 kali; (b) Plot PACF setelah differencing 1 kali

Berdasarkan Gambar 3, diketahui ada beberapa model ARIMA yang bias digunakan untuk peramalan produksi padi. Penentuan model ARIMA terbaik ditentukan berdasarkan nilai RMSE atau nilai MAPE terkecil. Model ARIMA yang dapat dibentuk berdasarkan plot ACF dan PACF diatas ditunjukkan pada Tabel 3

Tabel 3. Model tentative ARIMA produksi padi di Provinsi Gorontalo

\begin{tabular}{ccc}
\hline Model & parameter & RMSE \\
\hline ARIMA $(1,1,1)$ & signifikan & 14237.41 \\
ARIMA $(1,1,2)$ & Tidak signifikan & 14288.92 \\
ARIMA $(3,1,1)$ & Tidak signifikan & 16219.58 \\
ARIMA $(3,1,3)$ & signifikan & 13160.35 \\
\hline
\end{tabular}

Tabel 4. Uji asumsi white noise

\begin{tabular}{cccc}
\hline Model & p-value & $\alpha$ & keterangan \\
\hline ARIMA $(1,1,1)$ & 0.000 & 0.05 & Tidak terpenuhi \\
ARIMA $(1,1,2)$ & 0.001 & 0.05 & Tidak terpenuhi \\
ARIMA $(3,1,1)$ & 0.012 & 0.05 & Tidak terpenuhi \\
ARIMA $(3,1,3)$ & 0.180 & 0.05 & Terpenuhi \\
\hline
\end{tabular}


Berdasarkan Tabel 3 diketahui bahwa model ARIMA terbaik adalah model arima $(3,1,3)$ karena mempunyai RMSE terkecil. Hal ini didukung juga oleh Tabel 4 dimana diketahui bahwa model ARIMA $(3,1,3)$ memenuhi asumsi white noise. Oleh karena itu, model ARIMA terbaik yang dipilih adalah model ARIMA $(3,1,3)$ karena memenuhi asumsi residual white noise dan memiliki RMSE terkecil.

4. Uji parameter model ARIMA menggunakan uji$t$.

Berikut ini merupakan hasil estimasi parameter ARIMA $(3,1,2)$ menggunakan Minitab 16.

Tabel 5. Estimasi parameter ARIMA (3,1,2) untuk peramalan produksi padi di Provinsi Gorontalo

\begin{tabular}{cccc}
\hline Model & parameter & Estimasi & p_value \\
\hline ARIMA & $\phi_{1}$ & -2.0088 & 0.000 \\
$(3,1,3)$ & $\phi_{2}$ & -1.9581 & 0.000 \\
& $\phi_{3}$ & -0.8259 & 0.000 \\
& $\theta_{1}$ & -0.9443 & 0.000 \\
& $\theta_{2}$ & -0.4397 & 0.084 \\
& $\theta_{3}$ & -0.6460 & 0.006 \\
\hline
\end{tabular}

Tabel 5 diatas menunjukkan bahwa untuk taraf signifikansi $(\alpha=5 \%)$ hampir semua parameter signifikan, kecuali parameter MA(2) yang memiliki p-value $>\alpha=5 \%$. Berdasarkan estimasi parameter diatas, dapat dibentuk model ARIMA $(3,1,3)$ sebagai berikut.

$$
\phi_{3}(B)(1-B)^{1} Y_{t}=\theta_{3}(B) e_{t}
$$

yang dapat diuraikan menjadi:

$$
\begin{aligned}
& \phi_{3}(B)=\left(1+2.0088 B+1.9581 B^{2}+0.8259 B^{3}\right) \\
& \theta_{3}(B)=\left(1+0.9443 B+0.4397 B^{2}+0.6460 B^{3}\right)
\end{aligned}
$$

atau dapat dituliskan dalam bentuk berikut.

$$
Y_{t}=k_{1}+k_{2}
$$

dimana:

$$
\begin{aligned}
& k_{1}=3.0088 Y_{t-1}-0.0507 Y_{t-2}-1.1322 Y_{t-3}-0.8259 Y_{t-4} \\
& k_{2}=\left(1+0.9443 e_{t-1}+0.4397 e_{t-2}+0.6460 e_{t-3}\right) \\
& Y_{t}=\text { merupakan ramalan produksi padi tahun ke- } t \\
& Y_{t-1}=\text { merupakan produksi padi tahun ke } t-1 \\
& Y_{t-2}=\text { merupakan produksi padi tahun ke } t-2 \\
& Y_{t-3}=\text { merupakan produksi padi tahun ke } t-3
\end{aligned}
$$

model peramalan ARIMA $(3,1,3)$ menunjukkan bahwa produksi padi di Gorontalo dipengaruhi oleh produksi padi pada 1, 2, 3, dan 4 tahun sebelumnya.
5. Uji independensi, uji normalitas, dan white noise pada residual model ARIMA

Uji indepedensi residual ini dilakukan dengan melihat pasangan plot ACF dan PACF residual yang dihasilkan oleh model. Selanjutnya membandingkan nilai p-value pada output Ljung Box dengan taraf signifikansi yang digunakan.

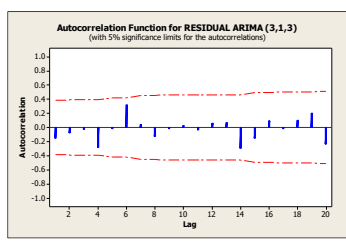

(a)

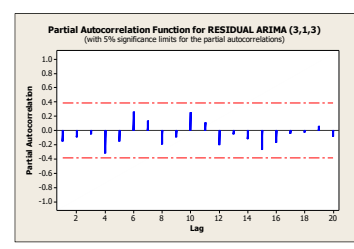

(b)
Gambar 4. (a) Plot ACF residual ARIMA (3, 1, 3); (b) Plot PACF residual ARIMA $(3,1,3)$

Gambar 4 menunjukkan bahwa residual tidak saling berkorelasi. Hal ini dibuktikan dengan tidak adanya lag yang melewati garis merah (cut-off) pada plot ACF dan plot PACF.

Tabel 6. Uji Asumsi normalitas dan white noise

\begin{tabular}{cccc}
\hline Asumsi & $\mathrm{p}$-value & $\alpha$ & keterangan \\
\hline normalitas & $>0.150$ & 0.05 & Terpenuhi \\
White noise & 0.180 & 0.05 & Terpenuhi \\
\hline
\end{tabular}

Selain menggunakan plot ACF dan PACF, untuk mengetahui apakah asumsi independensi dan white noise terpenuhi, dapat dilihat dari output Ljung Box. Nilai p-value dari Ljung Box (asumsi white noise pada Tabel 6) adalah 0.180. Hal ini berarti bahwa asumsi white noise terpenuhi. Begitupun untuk asumsi normalitas yang menghasilkan nilai $\mathrm{p}$-value $>0.150$ sehingga menunjukkan bahwa asumsi normalitas terpenuhi. Oleh karena semua asumsi terpenuhi, maka model ARIMA $(3,1,3)$ layak digunakan untuk melakukan peramalan produksi padi di Provinsi Gorontalo

\subsection{Perbandingan Akurasi Model Peramalan Produksi Padi di Provinsi Gorontalo}

Untuk memilih model terbaik dalam peramalan produksi padi di Provinsi Gorontalo, peneliti menggunakan nilai RMSE (Root Mean Square Error) sebagai dasar pengambilan keputusan. Model peramalan yang dipilih adalah model yang memiliki nilai RMSE terkecil. Perbandingan akurasi model peramalan produksi padi ditampilkan pada Tabel 7 . 
Tabel 7. Estimasi parameter ARIMA (3,1,2) untuk peramalan produksi padi di Provinsi Gorontalo

\begin{tabular}{cc}
\hline Model Peramalan & RMSE \\
\hline Holt-Winters (multiplikatif) & 19859.60 \\
ARIMA $(3,1,2)$ & 13160.35 \\
\hline
\end{tabular}

Berdasarkan Tabel 7 diketahui bahwa model terbaik untuk peramalan produksi padi di Provinsi Gorontalo adalah model peramalan dengan metode ARIMA $(3,1,3)$ karena model ini memberikan nilai RMSE terkecil yakni 13160,35.

Hasil peramalan produksi padi ditampilkan pada Tabel 8.

Tabel 7. Hasil peramalan produksi padi di Provinsi Gorontalo Tahun 2019

\begin{tabular}{cc}
\hline Periode & Produksi Padi \\
\hline Januari - April 2019 & 52816 \\
Mei - Agustus 2019 & 133084 \\
September - Desember 2019 & 126174 \\
\hline
\end{tabular}

\section{KESIMPULAN}

Berdasarkan uraian pembahasan dapat disimpulkan bahwa model peramalan terbaik untuk produksi padi di Provinsi Gorontalo adalah model peramalan dengan metode metode ARIMA $(3,1,3)$ karena memberikan nilai RMSE terkecil. Hasil proyeksi menunjukkan bahwa produksi padi di Provinsi Gorontalo untuk tahun 2019 untuk periode januari-april cenderung menurun dibandingkan tahun sebelumnya, akan tetapi pada periode selanjutnya produksi padi meningkat dibandingkan periode meidesember pada tahun sebelumnya. Produksi padi tidak hanya bergantung pada musim atau keadaan cuaca, tapi juga dipengaruhi oleh kebijakan dari pemerintah setempat dalam bidang pertanian.

\section{SARAN}

Dalam menyusun model peramalan produksi padi sebenarnya perlu memperhatikan faktor-faktor lain yang turut mempengaruhi produksi padi, seperti luas tanam, luas panen, serangan penyakit, keadaan iklim dan cuaca, dll. Oleh karena itu, disarankan dalam penelitian selanjutnya mungkin dapat menggunakan metode ARIMAX untuk peramalan sehingga faktor-faktor yang mempengaruhi produksi padi dapat dimasukkan dalam model peramalan produksi padi selanjutnya.

\section{DAFTAR PUSTAKA}

Aisha, S.M. (2016). Pemodelan Seasonal Generalized Space Time Autoregressive (SGSTAR) studi kasus: produksi padi di Kabupaten Demak, Kabupaten Boyolali dan Kabupaten Grobogan. Semarang: Universitas Diponegoro [skripsi].

Badan Pusat Statistik [BPS . (2018). Badan Pusat Statistik Provinsi Gorontalo.

Hutasuhut, A.H., W. Anggraeni, dan R. Tyasnurita. 2014. Pembuatan aplikasi Pendukung Keputusan untuk Peramalan Persediaan Bahan Baku Produksi Plastik Blowing dan Inject menggunakan Metode ARIMA Di CV. Asia. Jurnal Teknik ITS 3(2), 169-174.

Krismiasari, S. 2012. Prediksi produksi padi di Kabupaten Kapar dengan metode BoxJenkins. Pekanbaru: UIN Sultan Syarif Kasim Riau [skripsi]

Nugraha, D., Made, OA. I Putu, W. (2018). Pendugaan Produksi dan Tantangan Usahatani Kedelai di Indonesia menggunakan Metode ARIMA. Jurnal Penelitian Pertanian Tanaman Pangan, 22(3), 155-163.

Nurrohmah, N. (2016). Analisis produksi dan pendapatan petani padi sawah Kecamatan Mowila Kabupaten Konawe Selatan. Kendari; Universitas Halu Oleo [skripsi].

Ramadhona, G., Budi, D.S. Fitri, A.B. (2018). Prediksi Produktivitas Padi menggunakan Jaringan Syaraf Tiruan Backpropagation. Jurnal Pengembangan Teknologi Informasi dan Ilmu Komputer, 2(12), 6048-6057.

Safitri, T. (2016). Perbandingan peramalan menggunakan metode exponential smoothing Holt-Winters dan ARIMA. Semarang: UNNES [skripsi].

Wei, W.W.S. (2006). Time Series Analysis Univariate and Multivariate Methods second edition. USA: Pearson Education, inc. 